Intuizione e forma. André Jolles: vita, opere, posterità

\title{
A Promising Young Man: André Jolles Portrayed by Jan Veth and Jan Toorop
}

Un jeune homme promettant: André Jolles dans les portraits de Jan Veth et de Jan Toorop

Un giovane promettente: André Jolles nei ritratti di Jan Veth e Jan Toorop

Anton van der Lem

\section{OpenEdition}

\section{Journals}

Electronic version

URL: http://journals.openedition.org/cei/3067

DOI: 10.4000/cei.3067

ISSN: 2260-779X

\section{Publisher}

UGA Éditions/Université Grenoble Alpes

\section{Printed version}

Date of publication: 30 December 2016

Number of pages: $29-43$

ISBN: 978-2-84310-337-7

ISSN: 1770-9571

\section{Electronic reference}

Anton van der Lem, "A Promising Young Man: André Jolles Portrayed by Jan Veth and Jan Toorop", Cahiers d'études italiennes [Online], 23 | 2016, Online since 23 January 2017, connection on 27 March 2021. URL: http://journals.openedition.org/cei/3067 ; DOI: https://doi.org/10.4000/cei.3067 


\title{
A PROMISING YOUNG MAN: ANDRÉ JOLLES PORTRAYED BY JAN VETH AND JAN TOOROP
}

\author{
Anton van der Lem \\ Universiteit Leiden
}

From an international point of view André Jolles still has a certain renown as the author of his Einfache Formen (Leipzig, Max Niemeyer, 1930), translated in many languages. In his native country, Holland, he is also known as the close friend of Johan Huizinga (I872-1945), the famous Dutch histo-

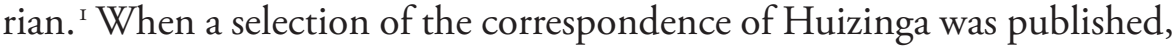
two of the three volumes contained many letters written by Jolles. ${ }^{2}$ This caused in the Netherlands a modest and quite temporary revival in the interest for Jolles, though nobody wished to deal in a more extensive way with his life and works. The exception was the Belgian scholar Walter Thys (1924-20I5), who published an exhaustive biography of Jolles, including many full-text sources. ${ }^{3}$ Among the readers of Huizinga's correspondence the reactions to Jolles' letters were quite contradictory. People appreciated Jolles because of his wit and imagination, his astonishing ideas, his enthusiasm and lively way of writing. Others considered him almost as a charlatan, a make-believe, not a man of appropriate learning. Some even suggested that many letters by Jolles would better have been let out of the publication. ${ }^{4}$ But as an author with the stature of Huizinga appreciated Jolles as a man of ideas and talents, we must be careful. When Huizinga, an erudite man and experienced researcher, held Jolles in esteem, there must have been something very attractive in Huizinga's friend, to prevent

I. In my biography, Johan Huizinga: Leven en werk in beelden en documenten (Amsterdam, Wereldbibliotheek, 1993), I dedicated chapter 9 entirely to André Jolles.

2. J. Huizinga, Briefwisseling, L. Hanssen, W. E. Krul, A. van der Lem (ed.), Utrecht, Antwerpen, Uitgeverij L. J. Veen, 1989-I99I, 3 vols.

3. W. Thys (ed.), André Jolles (I874-1946), 'gebildeter Vagant': Brieven en documenten, Amsterdam, Leipzig, Amsterdam University Press, Leipziger Universitätsverlag, 2000.

4. Though not in written form, this was suggested me to by the academics A. E. Cohen (Leiden) en J. C. H. Blom (Amsterdam). 
us from blaming him in advance. On the other hand, André Jolles was such a spoiled child in his youth, and he behaved himself during his entire career like that, that we could easily value him as a posing charmeur, cheating almost everyone, Huizinga included.

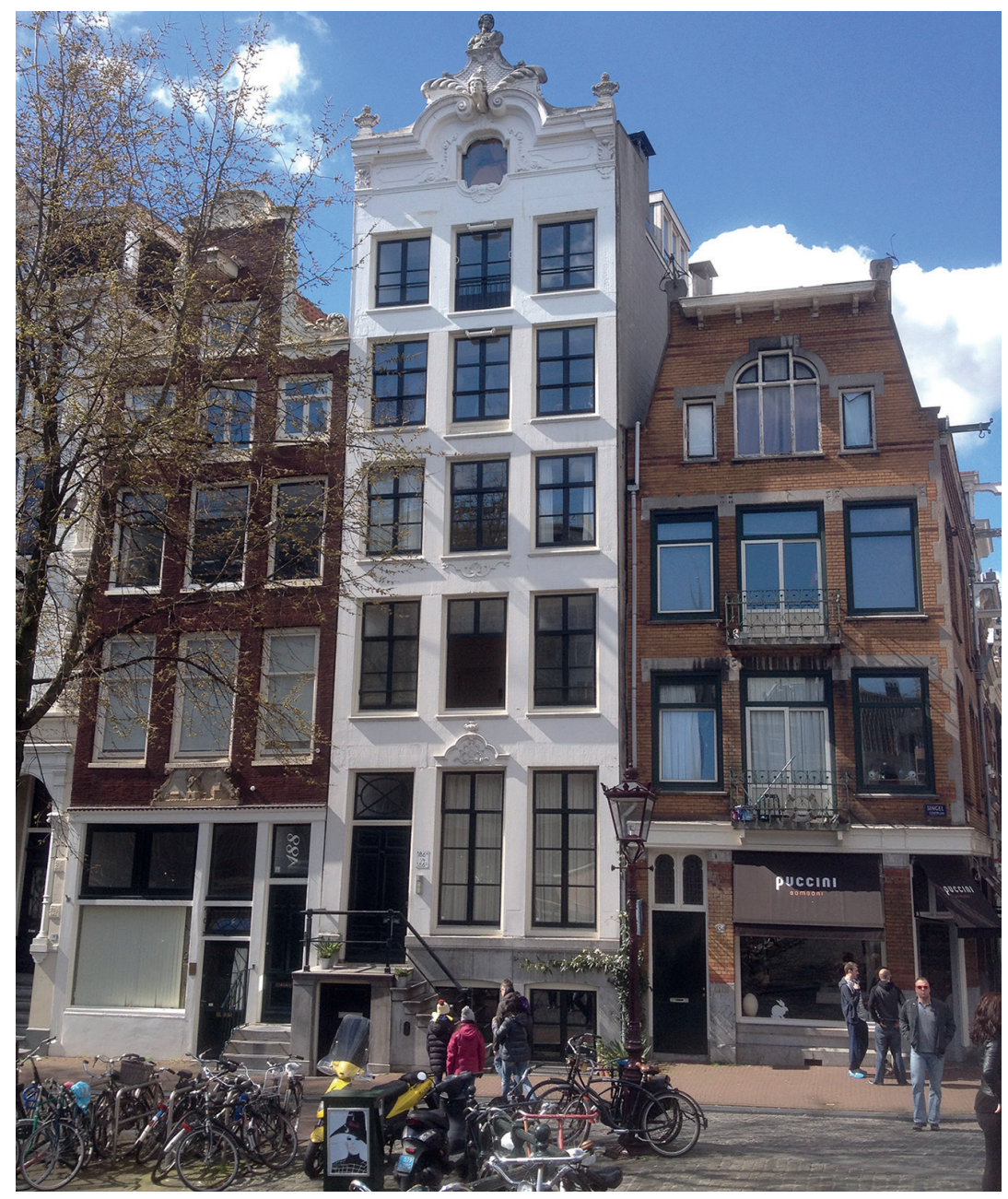

Fig. I. - Amsterdam, The Singel, where Jolles and Huizinga met for the first time.

Amsterdam, Anton van der Lem.

André Jolles and Johan Huizinga met for the first time in October 1896, in Amsterdam. Jolles and his mother had just moved to an apartment at one of the canals, the Singel I86, in the very heart of the town (fig. I). Huizinga would be 24 years old on December 7 of the same year. Jolles 
was two years his younger. Huizinga was in his final year as a student at Groningen University, his main interests being the Sanskrit language and comparative linguistics. He took as well a vivid interest in everything which concerned contemporary art and literature. With a couple of likeminded students he organized modest exhibitions of modern art and lectures to be given by renowned guests. Having the idea of inviting Jolles to give a lecture in Groningen, Huizinga went to Amsterdam to make acquaintance with him. It was the beginning of a friendship that would last until 1933, when Jolles joined the National-socialist party of Adolf Hitler, what Huizinga could not accept. The letters offer us a good insight in their common interest, be it that only the letters written by Jolles have survived. He has probably destroyed the letters addressed to him by Huizinga, when their friendship had come to an end.

At the same time there are still "gaps" in our knowledge concerning their friendship. Only one photograph survived, showing both Huizinga and Jolles (fig. 2). They are on the right side of the photograph, Jolles standing in front. Huizinga behind Jolles, putting a hand on his shoulder, in a movement

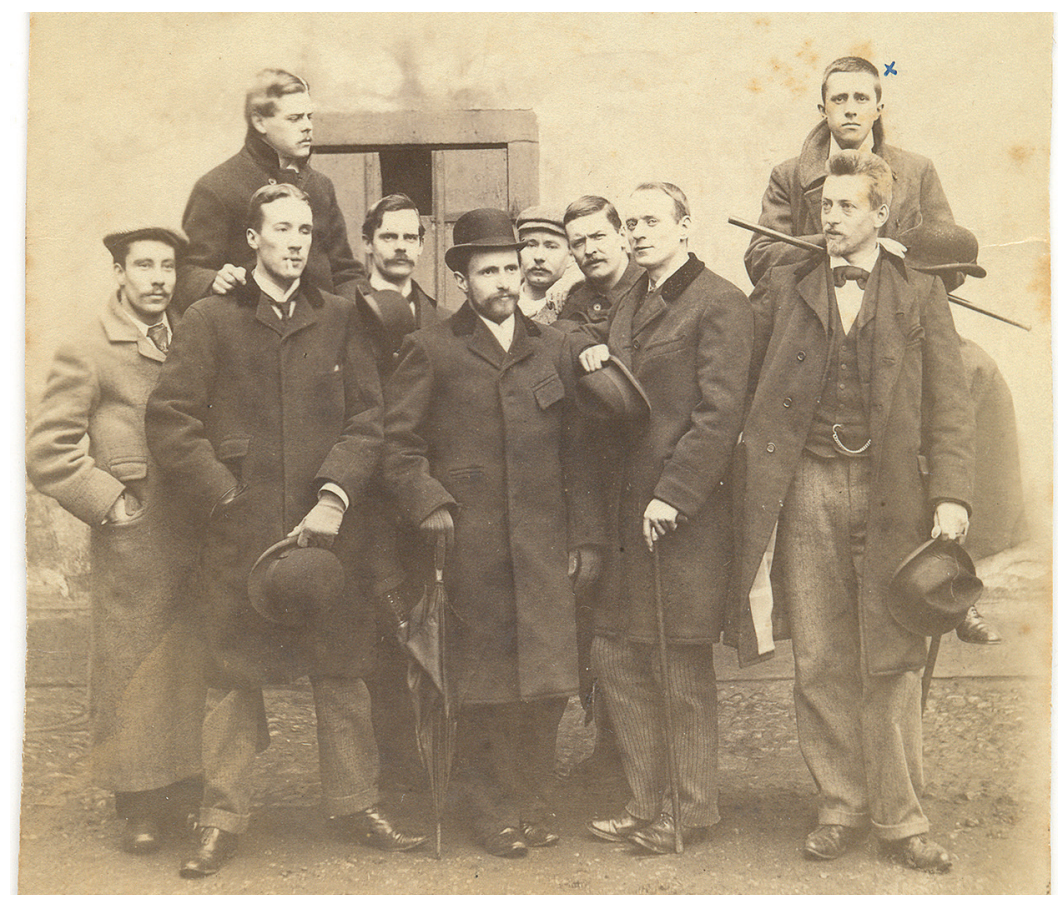

Fig. 2. - Who, where, when? A so far unknown company.

On the right Jolles and Huizinga.

Leiden, University Library, Huizinga Archives. 
of supporting Jolles, or supporting himself, or affirming by this their friendly relationship. The other persons on the photograph are seemingly a couple of students. The man in the middle, with the hat, is obviously the guest. But who is he? A painter, an author? Or is he someone else?

\section{The salon of Mrs Jolles}

André Jolles was born on August 7, I874, as the only child of Hendrik Jolle Jolles (I847-I888) and Jacoba Catharina Jolles-Singels (I847-I9OI). His native town was Den Helder, the major harbor of the Dutch Royal Navy, where his father served as a lieutenant. After the navy service the family moved to Amsterdam, where Hendrik Jolles became a stockbroker, just like his father. His wife published and translated several novels and invited authors and painters at her home where she held a modest salon. Because of the bad health of Hendrik Jolles, the family was regularly for rather long stays in Italy, with the consequence that André was frequently absent from his gymnasium in Amsterdam. When his father died in Italy on February 25, I888, Andrés education became the sole responsibility of his mother. She adored him though she was aware of his weak sides, but she couldn't handle him. He left the gymnasium without a diploma, his head full of ideas of becoming an author or an organizer of events, or an art historian but not (yet) troubled by the thought of how to make a living out of that. Over the years Mrs Jolles expressed her concern about André to several of her correspondents: André would now have done his final examination of the gymnasium, had his father lived; or: André would now have been a university student and living on his own. Instead André was spending the night studying the arts and laying the greatest part of the day in his bed; or: André is lazy but should necessarily go to Florence. ${ }^{5}$

Any other boy of this temper would probably have lost his career, if the cercle or salon of his mother would not have taken notice of André. We know that he discussed on equal terms with the Dutch poet Herman Gorter (I864-I927), with the portrait painter Jan Pieter Veth (I864-I925) and with the internationally famous painter from the Dutch East-Indies Jan Toorop (I858-1928). Another frequent visitor of the salon of Jolles' mother was the politician and journalist Pieter L. Tak (I848-1907). His lasting achievement was an attractive political and cultural weekly, 


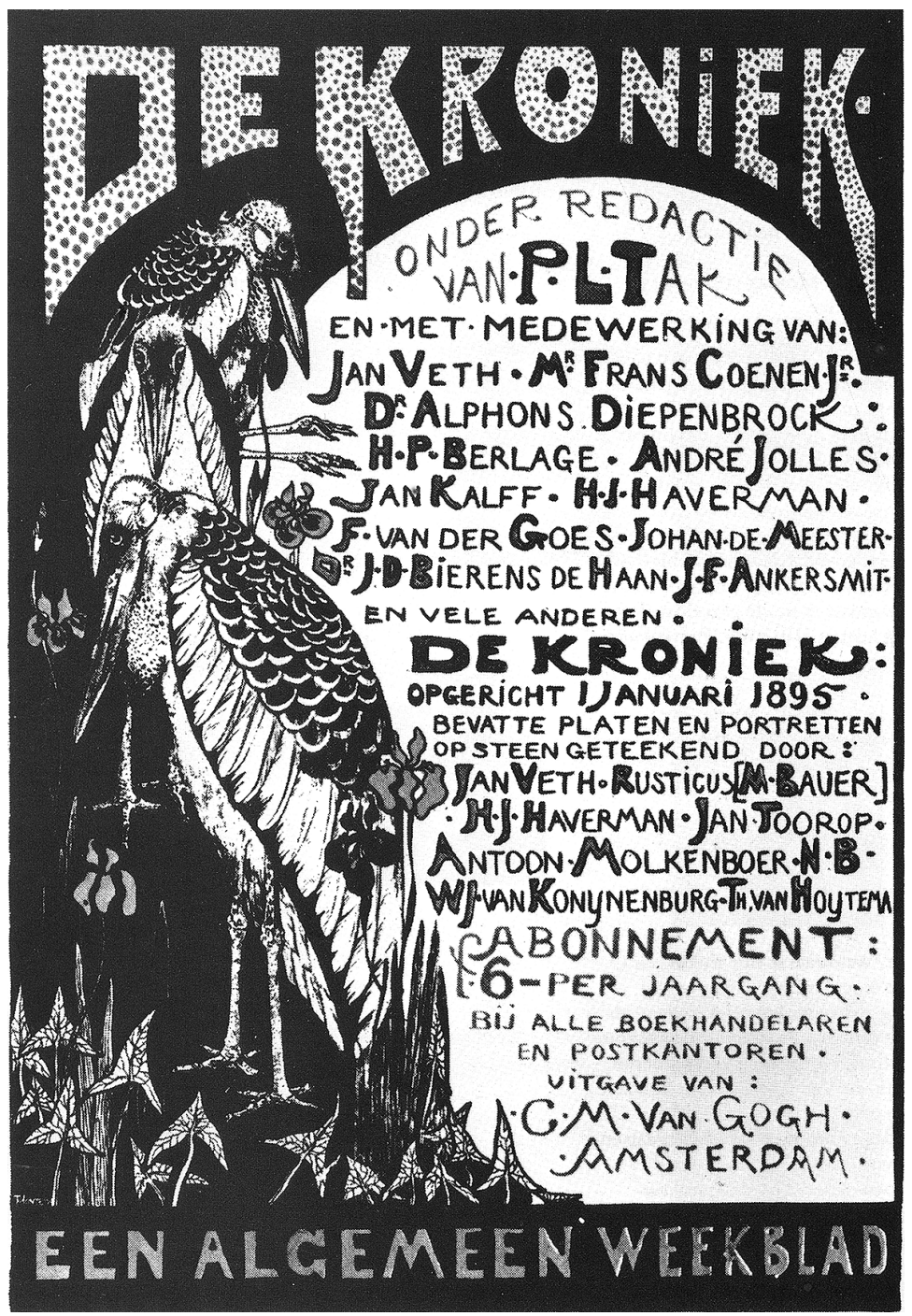

Fig. 3. - De Kroniek, cover.

Leiden, University Library.

De Kroniek, which was published from I January, I895, until the year of Tak's death in 1907 (fig. 3). As editor in chief he offered a platform for political writings as well as for the arts and humanities. De Kroniek is still famous for Huizinga's saying: "the best journal I have ever known". In De Kroniek authors and readers offered and experienced the more or less harmonious shift from the l'art pour l'art movement of the I880s in the Netherlands to the general attitude of the I89os: politics and arts in 
their responsibility to society. In De Kroniek wrote all those who visited Mrs Jolles, including her son André.

Fascinated during his stay in Florence by the late Medieval and early Renaissance Italian painting, Jolles contributed to the journal a series entitled The Primitives. ${ }^{6}$ These articles draw Huizinga's attention to Jolles. In another series, subscribed with the nickname Piet de Smeerpoets-Peter Mucky Pup-Jolles wrote fanciful articles teasing and blaming his contemporaries. ${ }^{7}$ Nowadays the sense of humor to appreciate these articles has long been lost, but also in his own time critics were negative about these supposedly funny contributions by Jolles. A member of the families that were really part of Amsterdam's upper class, a van Tienhoven, who apparently knew the Jolles family well, judged the provocative articles written by André Jolles in De Kroniek as the result of "hereditary family oddities". ${ }^{8}$

\section{The portraits by Jan Veth}

Mrs Jolles knew Jan Pieter Veth from her native Dordrecht, the oldest town of the province of Holland. She had been a friend of his parents and did see Jan Veth growing up and becoming Holland's leading portrait painter. When André (fig. 4) was three years old, she asked Jan Veth to make a drawing of him. It is a modest accomplishment in grey chalk, revealing André more as a naughty, sad boy than as the loving child adoring his parents. Jan Veth appreciated the support of Mrs Jolles, as he wrote to her in I886: "You are the first in the world who showed me real cordial kindness." " In I884 he had portrayed Mrs Jolles (fig. 5) and her husband. The reactions must have been positive, because Veth reported: "With the portraits of Mrs and Mr Jolles I had a lot of success, and it is now time to make something truly unsuccessful." "o What was wrong with having success? In his early years Veth wanted to be, if not a revolutionary artist, then at least one to renew the art of portraiture in his country. "I want to be a wild,

6. It became the series Primitieven, in De Amsterdammer, 1894 (first series), and De Kroniek: een algemeen cultureel weekblad, I895 (second series). Details in W. Thys, André Jolles, op. cit., pp. I027-8.

7. [A. Jolles], "Brieven van Piet den Smeerpoets", De Kroniek, from January I895 to January I899. Details in W. Thys, André Jolles, op. cit., pp. I028-30.

8. Ibid., p. I59 ("hereditaire familieeigenschappen").

9. "U is de eerste die mij in de wereld echte hartelijke vriendelijkheid heeft betoond." (Ibid., p. 82.)

Io. "Met de portretten van meneer en mevrouw Jolles heb ik veel succes gehad, en het wordt tijd, dat ik eens iets maak, waar ik niets geen succes mêe heb." (J. Huizinga, Leven en werk van Jan Veth, Haarlem, Tjeenk Willink, I927, p. 2I.) 


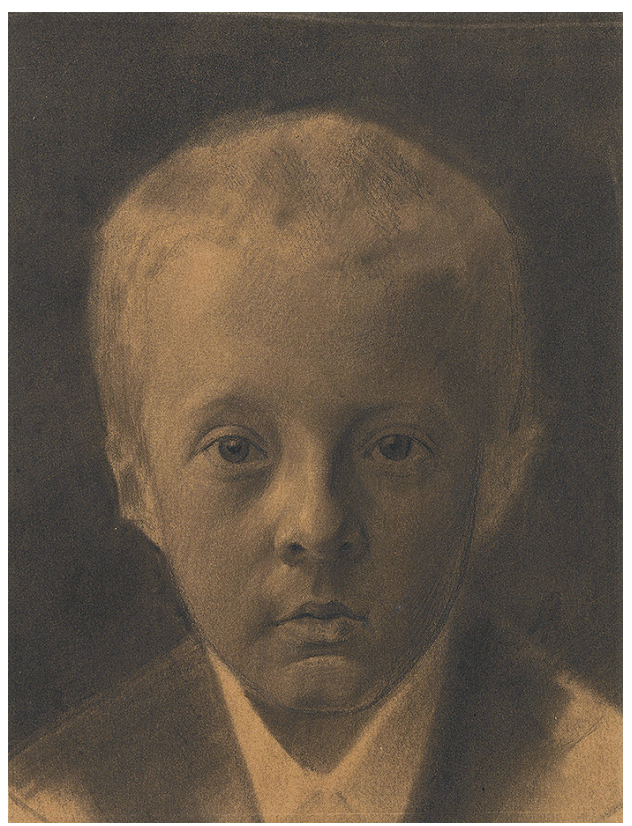

Fig. 4. - Jan Veth, portrait of André Jolles as a child.

Leiden, University Library, coll. Prentenkabinet.

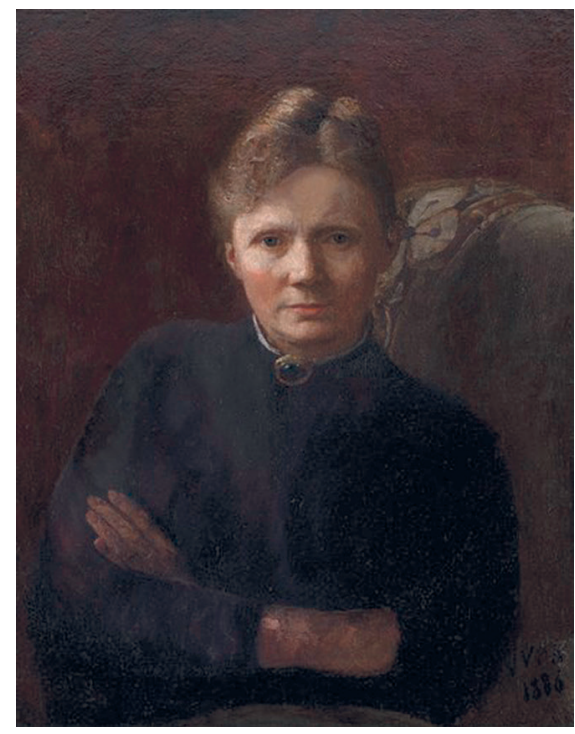

Fig. 5. - Jan Veth, portrait of Mrs J. C. Jolles-Singels, mother of André Jolles.

Dordrecht, Dordrechts Museum. 


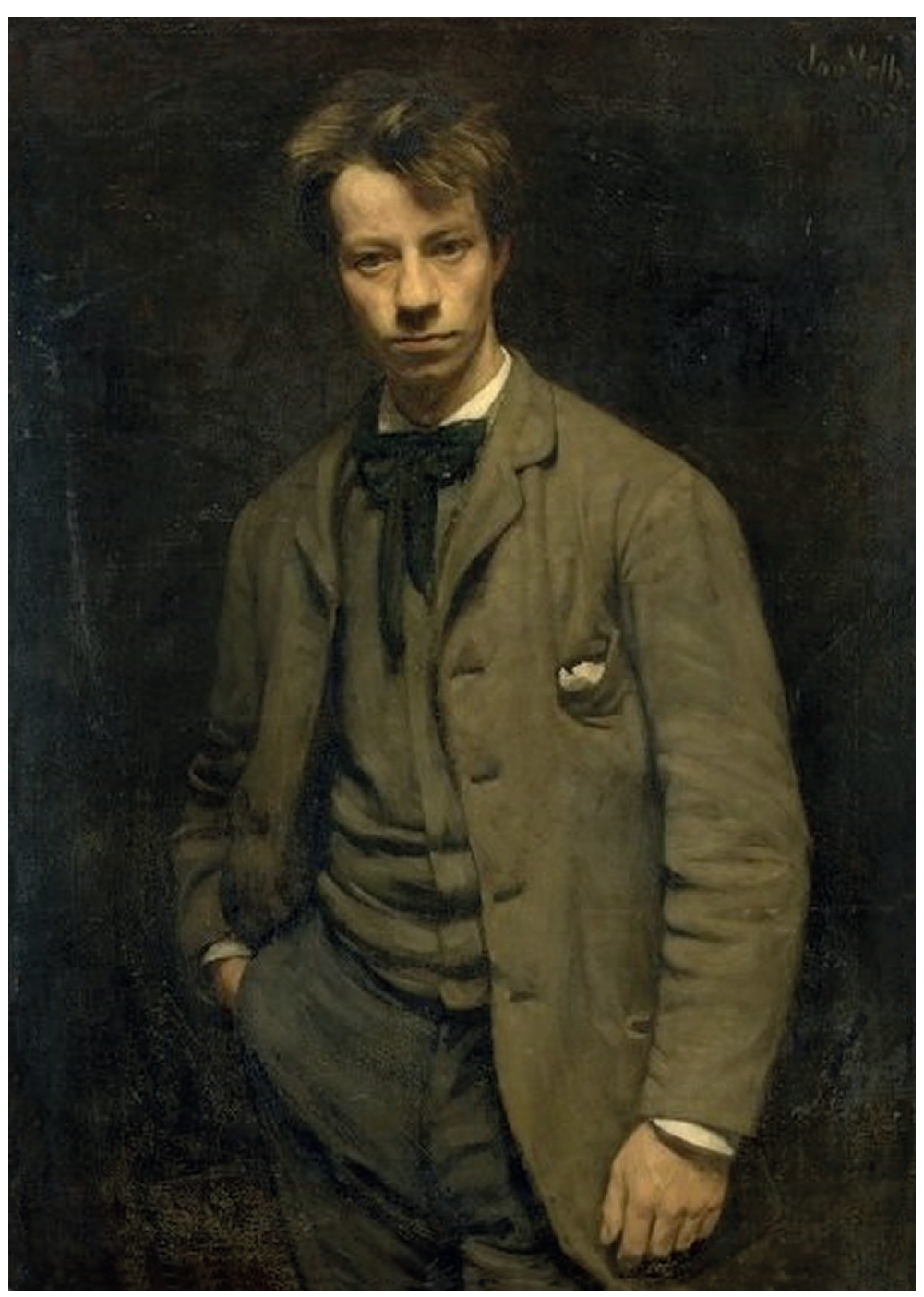

Fig. 6. - Jan Veth, portrait of the poet Albert Verwey. Amsterdam, Stedelijk Museum.

flamboyant artist", he wrote, with the wishful thinking of someone who eagerly wanted to be the opposite of what he knew to be his own natural character. An example of a "wild" painting was his unconventional portrait of the Dutch poet of the time Albert Verwey (fig. 6): not a stiff sitter but a nonchalant poète maudit. Painstakingly precise, Veth portrayed his subjects the way they were, for better or worse. Up until igrs he made dozens of portraits in Germany as well: artists and politicians or people from the 
trading and banking business. One was supposed to show courage and even some self-denial to "sit" for Jan Veth. One of the criticisms addressed to him was: "It would not be a pleasure for anybody to grant his face to the green-gray colors of Jan Veth." II

Revealing is what Mrs Jolles declared to Jan Veth: "You don't know how much I always longed that André would became a young man like you were at that age." ${ }^{12}$ Without any doubt she hoped that Jan Veth would have a positive influence on André, perhaps when André would be sitting for him, posing as a model. At the age of I8 (in I892) André was already travelling to Veth's atelier in Bussum-half an hour by train from Amsterdam - but nothing came out of it, undoubtedly because of Andrés lack of discipline. At the end of 1894 painter and sitter made a second attempt. When André didn't want to go to Bussum, Veth was supposed to come to Amsterdam, but André didn't have time because he preferred to play tennis. Mrs Jolles regretted Andrés "sad inertia" and would instead prefer "a good fling". She confessed that André was as tyrannical as his grandfather. ${ }^{\mathrm{I}}$

At last Jan Veth succeeded in meeting the wishes of Mrs Jolles to make a portrait of André- he even made two portraits. Both portraits are wonderful pieces of art-one should wish the character would have lived up to his representations. The first portrait was only a drawing of his face, made in 1894 when André was 20 years old. Mrs Jolles wrote to Jan Veth: "I would love to have a portrait of André now that he is twenty years old, with all his beautiful and awful sides, physically and morally." ${ }^{\text {I4 }}$ In the oeuvre catalogue of Veth this is number 29I, "colored drawing, without whereabouts". ${ }^{\text {Is }}$ Not mentioned in the oeuvre catalogue is the portrait by

II. Ibid., p. 36: "dat niemand er voortaan pleizier in zou hebben, zijn tronie aan Veth's groen-grijze verven over te geven".

I2. W. Thys, André Jolles, op. cit., p. II7.

13. This grandfather was Johannes Andreas Jolles (I816-190I), stockbroker, who was married twice. André Jolles was supposed to be a daughter and having the names Maria Magdalena. But when he proved to be a boy, he received the names of his grandfather: Johannes Andreas. In December 1932 André Jolles would write to his daughter: "I did regret it many times that I wasn't a girl." "Habe es als Kind auch manchmal bedauert, dass ich kein Mädchen war.” When André's father died, his grandfather lived in the South of the country and was apparently kept at a distance by André's mother, not willing to have her father-in-law involved in André's education. (W. Thys, André Jolles, op. cit., p. 820.)

I4. J. C. Jolles-Singels to Veth, 25 October I894: "Ik zou zoo heel graag een portret van André hebben nu hij twintig jaar is, met al zijn mooie en leelijke kanten physiek en moreel. Wilt gij hem eens voor mij schilderen? Gisteren was hij bij mij en hij vond dat idee van mij om hèm te hebben, door U, erg genoegelijk, en had wel tijd om te poseeren. De betaling gaat dan weer per maand, dat is voor mij makkelijk en gij vindt dat niet nàar. André was zoo vol over het portret van mevrouw Boxman [...].” (W. Thys, André Jolles, op. cit., p. 56.)

I5. Huizinga's book on Jan Veth contains an oeuvre catalogue, not drawn up by Huizinga himself but by the heirs of Jan Veth, undoubtedly based upon his order book. 


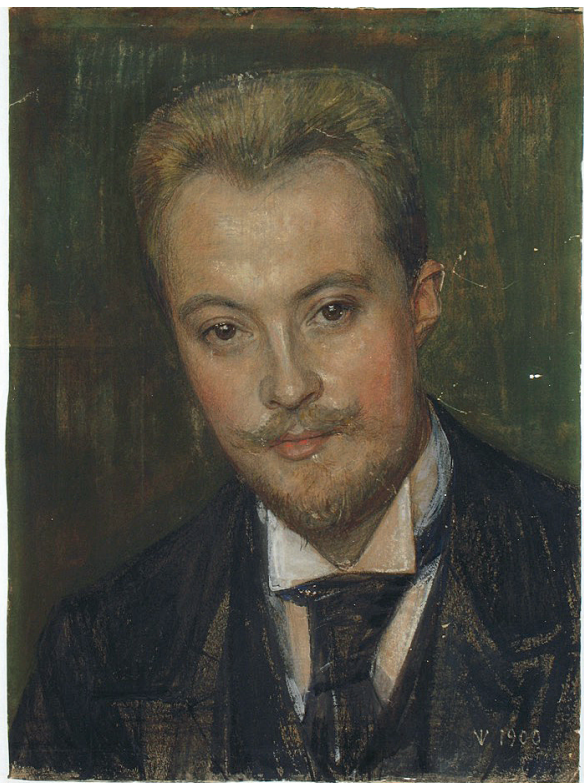

Fig. 7. - Jan Veth, portrait of André Jolles, I894, made over in 1900.

Private collection.

Jan Veth (fig. 7), clearly signed in the lower right corner: I and V (which stand for Jan Veth), 1900. In my opinion this is in all probability a remake of the drawing of I894. The drawing was in gouache, reworked with oil paint. There is no photograph of the original 1894 drawing, so we had in a way three portraits by Jan Veth of Jolles as a young man: the original of I894, the portrait of 1896 (fig. 8) and the makeover portrait of 1900 (fig. 7).

When the work on the portrait of 1896 was interrupted because André was unwilling to get up early in the morning to pose for Jan Veth, Mrs Jolles comforted the painter: "I am already so profoundly happy and delighted with the drawing [of $\mathrm{I} 894, \mathrm{AvdL}$ ], on which he is so perfect, just like I see him now almost all the time." ${ }^{16}$ It must have been for Jan Veth a work of self-denial to fulfill the demands of portraying André Jolles. He achieved his task in order to please Mrs Jolles, no doubt. This time it is an oil painting on panel. It shows André in almost full length, sitting in

I6. J. C. Jolles-Singels to Veth, undated, [1896]: "André is erg weinig voor dat Dinsdags poseeren gestemd. Hij heeft dan 's avonds twee uur les en vooral het vroeger opstaan in den morgen is een hurdle daar hij moeielijk overheen kan. Maar Jan, als de jongen niet wil, laat dat dan geen bezwaar zijn, want ik ben al zoo innig blij en in mijn schik met de teekening waarop hij zoo volmaakt is juist zoo als ik hem nu haast altijd zie." (W. Thys, André Jolles, op. cit., p. I72.) 


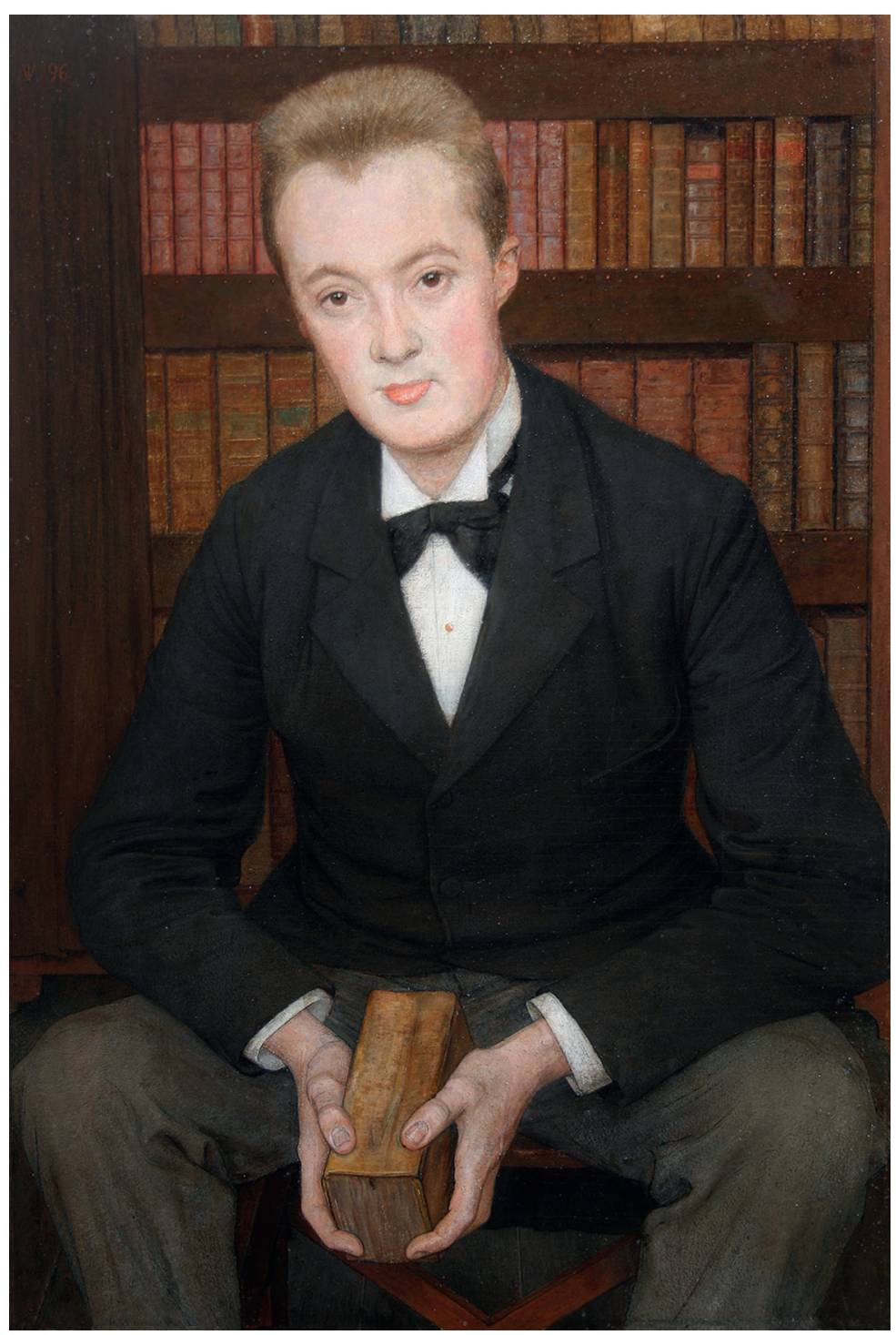

Fig. 8. - Jan Veth, portrait of André Jolles, I896. Private collection.

front of his library. He is looking straight into the eyes of the observer. He has an open face, as pale as a Dutchman can be, without traces of Italian sunshine. Blushes on his cheeks may suggest some liveliness, if they were not artificial. Does his tiny mouth predict the sarcasms of his Peter Mucky Pup articles? His slightly red hair is combed to the back in the same way as on the photograph with Huizinga (fig. 2). One is tempted 
to quote the saying in Holland: Rooien en valen benne donderstralen, so much as: "red hairs and pale skins (albinos) are rascals". He is dressed à la mode without overdoing it, not to say that he was quite conventional. The books on every shelf are prevented from collecting dust by the green short anti-dust curtains hanging from the shelves above: probably, the beloved Symbolists which he possessed thoroughly. On the other hand there is a more negative expression by Jolles, from about the time the portrait was made: "At the moment there is nothing in the world in which I take pleasure. I am bored and all around me there are beautiful, wise books in which I don't take interest." ${ }^{17}$ Remark that the books are standing in a perfect order on the shelves, as if untouched for a long time and the book he is holding in his hands is closed. Are we to conclude from the painting that he considered himself a self-confident reader, quite certain to become a writer of his own? Or does the painting represent him already as the pretender he would remain his entire life?

Having a second look on the portrait by Jan Veth of I894, reworked by the painter in 1900, probably on request of André or of his mother, André is now represented en buste, this time not with a bow tie, but an ordinary one. The scholarly adolescent of 1896 has given place to a young man with a sunny face, friendly and sympathetic eyes, who enjoys life.

How André Jolles appreciated his portraits by Jan Veth is unknown. When Johan Huizinga wrote his biography of Jan Veth, he used the extensive correspondence of Jan Veth, including the letters written by André Jolles. Huizinga also quoted Jolles, only indicating him as "one of his [Veth's] friends". These quotations can not be verified in the Jan Veth papers, now in the library of the Rijksmuseum in Amsterdam, because the letters by Jolles have been removed, probably on his own request. When Huizinga had finished his manuscript he stayed with André Jolles in Leipzig and read it entirely aloud to him—-maybe because he was certain that if he had sent the manuscript, Jolles would have neglected it. ${ }^{18}$ To Jan Veth's widow Huizinga wrote that André had appreciated the biography and had given many useful minor additions and corrections. ${ }^{19}$ Contrarily

I7. "Er bestaat op 't oogenblik niets in de wereld waar ik lust in heb. Ik verveel me en om heen staan mooie wijze boeken die me niet interesseeren." (Ibid., p. II3.) Rumours say that his library was granted to or incorporated in the library of his Institute in Leipzig, where he was professor of Dutch literature since I9I8.

I8. In Huizinga's autobiographical sketch Mijn weg tot de historie (Haarlem, Tjeenk Willink, I947), of which the English translation is rather bad: "In juli 1927 heb ik het voltooide werk uit het manuscript voorgelezen aan André Jolles, die het bijzonder prees.” (p. 49)

19. J. Huizinga, Briefwisseling, op. cit., vol. II, nr. 718: Leiden, I6 juli 1927, to Anna Veth-Dirks: "Ik heb het geheel aan André kunnen voorlezen, die ermee ingenomen was en mij menige nuttige kleine aanvulling of correctie gaf." The manuscript of Huizinga's biography of Veth has not been traced. 
to the portraits of his own, André Jolles reacted very sharply to Jan Veth concerning the portrait Veth had made of Jolles' mother (above, fig. 4). I presume the quotation Huizinga has given from Veth's correspondence was written by Jolles

"It is cold, it has nothing of a poem", writes one of his best friends, whose mother he had painted, "and I was hoping that you would have made a sentimental work of it, as of Mrs. B...." And next, jestingly: "Are you pessimistic, little Jan? Shame, shame on you, you have reached your fortune too early." ${ }^{20}$

Where Huizinga tried to do his best to bring the friends together by saying that Jolles gave his opinion "jestingly", I think that Jolles in reality was jealous, not only of Veth's talent, but even more of Veth's discipline and hard working, qualities he himself entirely missed. Presumably Huizinga has returned in 1927 Jolles' letters to Veth back to André Jolles, who destroyed the letters for the same reason why he destroyed those of Huizinga many years later: he didn't want to be remembered of the bright years of his youth when the future seemed to offer him a life of culture and fame.

\section{The portrait by Jan Toorop}

Nothing of this turmoil is to be found in the pencil drawing of Jolles by Jan Toorop (fig. 9). Native of the Dutch East-Indies where he was born in Poerworedjo in 1858 , he came with his family to Holland in 1872 . During the decades around the turn of the century he was the most important and most influential Dutch painter of modern art, both nationally and internationally famous. He started as a symbolist painter, but to whatever style he changed, he was always focused on the dilemma that life is a painful battle between extremes: good and evil, tranquility and passion, the superior and the inferior. ${ }^{21}$ No letters reveal how and when the portrait has been made-probably André conformed to the orders of his mother

20. J. Huizinga, Jan Veth, op. cit., p. 36: "Maar ook zijn vrienden waren niet altijd zachtzinnig met hem. 'Het is koud; het heeft niets van een poeëm,'—-schrijft een zijner beste vrienden, wiens moeder hij geschilderd had-, 'en ik had gehoopt, dat ge er een sentimentstuk van zoudt maken als van Mevr. B...' 'Ik hoop, dat ge mijn moeder niet meer zult laten poseeren, want zij heeft er meer dan genoeg van.' En vervolgens, schertsende: 'Ben je pessimistisch, Jantje? Foei, foei, je hebt je geluk te gauw gekregen'.” For the portrait of Mrs B. = Mrs Klazina Christina Boxman-Winkler, oeuvre catalogue nr. 287, oil painting (whereabouts unknown), or nr. 290, coloured drawing, see <https:/www.dordrechtsmuseum.nl/objecten/id/dm-929-t8/> [last visited: July $202016]$.

2I. G. van Wezel, Jan Toorop: zang der tijden, The Hague, Zwolle, WBooks, 20I6, p. Iо. 


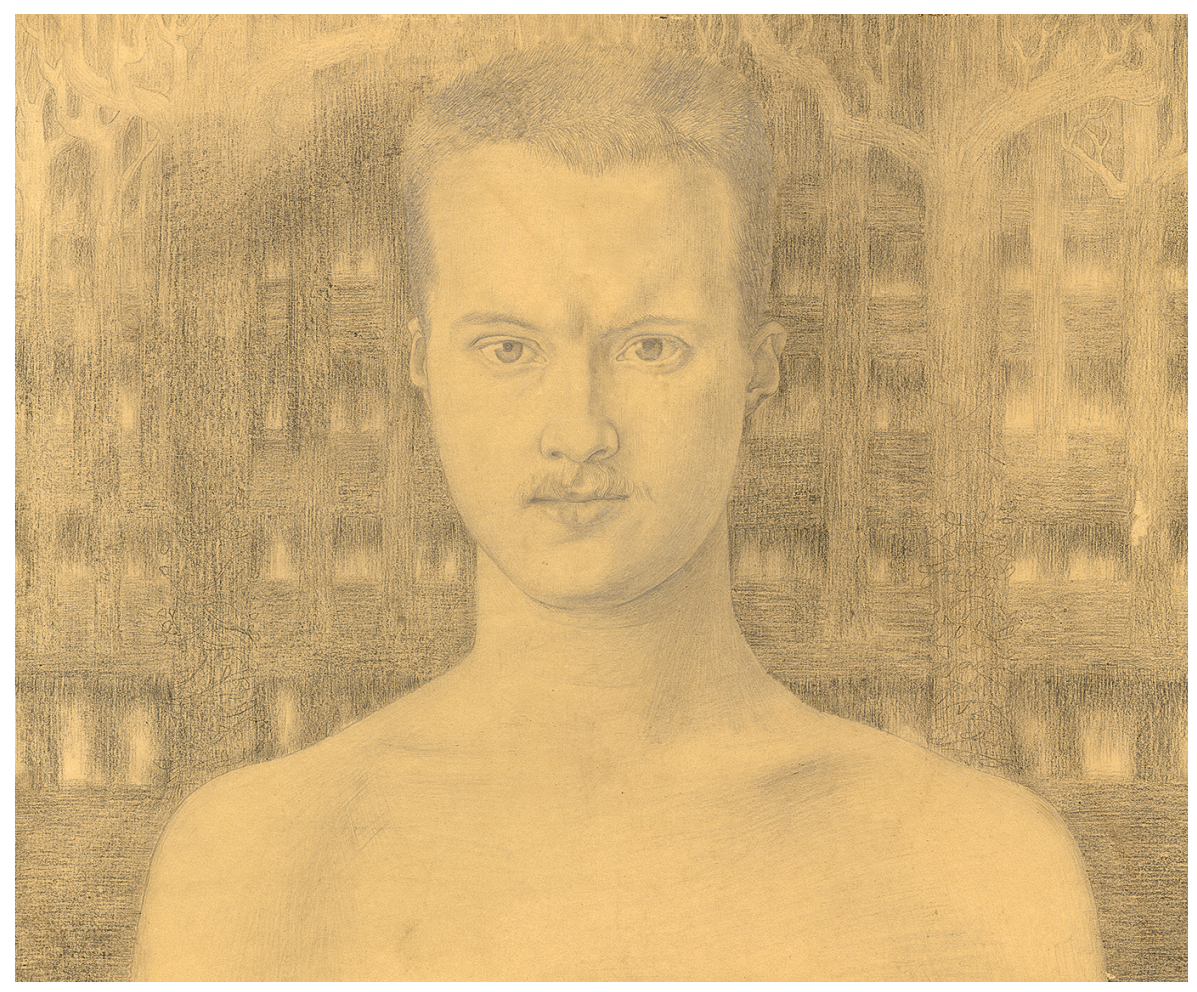

Fig. 9. - Jan Toorop, portrait of André Jolles, I895.

Private collection.

or was in the spell of the charisma of the artist. The only evidence is given by Toorop himself in the signature: I895. The drawing is made on fine Japan paper, pasted on cardboard. We see André en face, with his naked shoulders. Naked figures are quite common in the invented paintings of Jan Toorop, but not in his portraits. In this way the naked shoulders are quite an exception in Toorop's oeuvre. Thanks to the thorough and lifetime investigations of Gerard van Wezel, we can identify the background against which he placed his subject. Toorop worked regularly on the isle of Walcheren, in the Dutch province of Zeeland, where the bright light and wonderful nature attracted colonies of painters, especially in the coastal village of Domburg. In 1895 he stayed at the nearby country estate of Westhoven. The woods, crossed by the many brooks of the flat landscape, offered him the background of vertical and horizontal lines as they are clearly visible on the portrait of Jolles. The ivy, typical of Toorop in the works of this period, is winding itself around the trees as a symbol of eternal 
life. ${ }^{22}$ Will it have confirmed young André that eternal life would be his by his own achievements? One year later Toorop cordially cooperated to organize an exhibition in Groningen, with a group of interested students to which belonged Johan Huizinga (see above, fig. 2, p. 3I). Toorop not only made up the catalogue himself, but drew a special cover as well. He made some trips with the students to the Groningen countryside and once he even made a rapid sketch of the fresh and boyish Huizinga. On the backside it was named "Abeltje", little Abel, and this indication is the only help we have to rediscover this drawing, that has never been recovered since Huizinga mentioned it. Almost all models in the world are generally more known for having been portrayed by a well-known artist, than because of their own importance. That also turned out to be true for André Jolles. 